\title{
OCCUPATIONAL RISKS FOR SARS-COV-2 INFECTION: THE POLISH EXPERIENCE
}

\section{RADOSŁAW SIERPIŃSKI ${ }^{1,2}$, JAROSŁAW PINKAS ${ }^{3}$, MATEUSZ JANKOWSKI ${ }^{3}$, GRZEGORZ JUSZCZYK ${ }^{4}$, ROMAN TOPÓR-MĄDRY ${ }^{5,6}$, and ŁUKASZ SZUMOWSKI ${ }^{1,7}$}

${ }^{1}$ Cardinal Stefan Wyszyński University, Warsaw, Poland

Collegium Medicum

${ }^{2}$ Medical Research Agency, Warsaw, Poland

${ }^{3}$ Centre of Postgraduate Medical Education, Warsaw, Poland

School of Public Health

${ }^{4}$ Medical University of Warsaw, Warsaw, Poland

Department of Public Health

${ }^{5}$ Agency for Health Technology Assessment and Tariff System, Warsaw, Poland

${ }^{6}$ Jagiellonian University, Kraków, Poland

Collegium Medicum, Faculty of Health Sciences

${ }^{7}$ National Institute of Cardiology, Warsaw, Poland

Department of Cardiac Arrhythmia

\begin{abstract}
Objectives: The disease caused by the severe acute respiratory syndrome coronavirus 2 (SARS-CoV-2), termed COVID-19, is asymptomatic or mild in most cases. These patients do not need treatment in hospital and can be isolated at home. To date, most studies have been conducted among inpatients with severe COVID-19. In this study, the authors surveyed patients with mild COVID-19 who remained in home isolation, and analyzed the sources and occupational risk factors for SARS-CoV-2 infections. Material and Methods: This cross-sectional study was carried out on April 17-18, 2020, among patients infected with SARS-CoV-2 who remained in home isolation in Poland. Data were acquired through a structured interview that included questions about the isolation course, symptoms, comorbidities, infection source, household characteristics, occupation, and workplace. Data were presented with descriptive statistics. Results: Of the 4878 patients in home isolation, the authors were able to contact 3313 . Of them, 1191 patients declined their invitation, and 2122 agreed to take part. The median age of the patients included in the study was 50 years; $59 \%$ were female. Most patients ( $92 \%$ ) had not been abroad before the infection. More than half $(55 \%)$ knew how they became infected; of them, $75 \%$ became infected at work. Of all patients, $70 \%$ were occupationally active. Nearly half of the occupationally active patients (48\%) worked in healthcare, $3 \%$ worked in public administration or defense, $3 \%$ worked in transportation, and $2 \%$ worked in education. Sixty-five percent of the occupationally active patients worked in companies with >100 employees. Conclusions: Most of the patients with COVID-19 in home isolation in Poland were occupationally active, wherein the majority of people who were aware of the source of SARS-CoV-2 infection worked in healthcare. As most of the infected patients worked in companies with $>100$ employees, which is not a Polish employment pattern, the authors expect that smaller companies may have a lower risk of SARS-CoV-2 infections. Int J Occup Med Environ Health. 2020;33(6):781-9
\end{abstract}

Key words:

occupational exposure, public health, quarantine, coronavirus infection, patient isolation, cross-sectional survey

Funding: this study was supported by own resources of the Polish Medical Research Agency.

Received: May 23, 2020. Accepted: June 25, 2020.

Corresponding author: Jarosław Pinkas, Centre of Postgraduate Medical Education, School of Public Health, Kleczewska 61/63, 01-826 Warsaw, Poland

(e-mail: jaroslaw.pinkas@cmkp.edu.pl). 


\section{INTRODUCTION}

The severe acute respiratory syndrome coronavirus 2 (SARS-CoV-2) has spread throughout the world at an unprecedented rate. The epidemic started at the end of 2019 in China, and, as of May 7, 2020, there were >3 million confirmed cases worldwide [1]. Moreover, the high degree of asymptomatic infections and a lack of universal testing suggest that the true prevalence of SARS-CoV-2 infections is likely much greater [1,2].

Generally, SARS-CoV-2 causes a disease termed COVID19, which presents mainly with fever and respiratory symptoms, but other symptoms, such as loss of smell or diarrhea, may also occur [3]. The virus spreads primarily through respiratory droplets among people in close contact or through contact with the immediate environment of the infected person [4]. It is highly transmittable, with an estimated reproductive number twice as high as that of the influenza virus [5].

Due to the immense scale of the SARS-CoV-2 epidemic, healthcare systems worldwide are struggling to provide adequate patient care. As neither a vaccine nor effective treatments for COVID-19 are available, it is essential to limit public exposure to the virus [6-8]. In particular, it is important to isolate people with confirmed SARS-CoV-2 infections. Although about $80 \%$ of COVID-19 cases are asymptomatic or mild and do not need treatment in hospital $[9,10]$, these patients can still spread the disease and should be isolated at home [11]. In Poland, home isolation lasts for 14 days and is completed when nasopharyngeal swabs, taken on days 10-12, are negative for SARSCoV-2 [12].

To date, most published studies on COVID-19 have been conducted among inpatients with a severe disease form, whereas data for patients in home isolation are scarce. In this study, the authors surveyed people infected with SARS-CoV-2 who were in home isolation, with the aim of identifying the sources and occupational risk factors for the infection.

\section{MATERIAL AND METHODS}

\section{Study design and participants}

This cross-sectional studywas carried out on April17-18,2020, among non-hospitalized patients with the SARS-CoV-2 infection confirmed by reverse-transcription polymerase chain reaction (RT-PCR) of nasopharyngeal swabs. In Poland, patients who do not need treatment in hospital are isolated either in isolation centers or at home. The authors invited all patients who were in home isolation on April 17-18, 2020 to participate in this study; participation was voluntary. All procedures followed the ethical standards of the national research committee and the 1964 Helsinki Declaration (and its subsequent amendments). Laboratory testing for COVID-19 followed the European Centre for Disease Prevention and Control (ECDC) guidelines [13].

\section{Study procedures}

Data were acquired through a structured interview. The authors called the participants by phone and asked them about their isolation course, symptoms, comorbidities, infection source, household characteristics, occupation, and workplace. Table 1 shows the interview form with all questions. The obtained data were anonymized before the analysis. The Classification of Occupations and Specialties was based on the classification provided by Statistics Poland [14].

\section{Statistical analysis}

The authors used descriptive statistics to present data: medians and percentages. Due to the descriptive nature of the study, no inferential statistics were done.

\section{RESULTS}

\section{Participants}

As of April 17, 2020, contact details were available for 4878 patients in home isolation, but telephone numbers were available for 4516. Of them, 1203 patients could not be contacted, 1191 patients declined the invitation, and 
Table 1. Structured interview questions for patients infected with COVID-19 who remained in home isolation on April 17-18, 2020 (Warsaw, Poland)

\begin{tabular}{|c|c|}
\hline Question & Answer \\
\hline 1. Are you now in isolation? & Yes/No \\
\hline 2. Has your sanitary-epidemiological station informed you not to leave your home? & Yes/No \\
\hline 3. Are you in quarantine? Since when? & Yes/No \\
\hline 4. Have people from your household been tested for coronavirus? When? & Yes/No; date \\
\hline 5. Do the police check on you? How often? & Yes/No; frequency \\
\hline 6. Do you know when your quarantine ends? & Yes/No \\
\hline 7. Since your positive coronavirus test, have you been in contact with other people? & Yes/No \\
\hline $\begin{array}{l}\text { 8. Were you occupationally active at the time of the infection? If not, are you unemployed, } \\
\text { retired, on a pension? }\end{array}$ & Yes/No \\
\hline \multicolumn{2}{|l|}{ 9. What is your profession? (a list of professions from Statistics Poland) } \\
\hline \multicolumn{2}{|l|}{ 10. Where do you work? } \\
\hline \multicolumn{2}{|l|}{ 11. What is the type of your work? (Polish Classification of Activities codes) } \\
\hline 12. Do you know how you got infected? & Yes/No \\
\hline 13. If so, was the infection related to your work? & Yes/No \\
\hline 14. Does the infection with coronavirus make it impossible for you to work? & Yes/No \\
\hline 15. During the last 14 days, have you worked outside your home? & Yes/No \\
\hline 16. Do you know of any infections among other employees of your company? & Yes/No \\
\hline 17. Were you abroad up to 14 days before the infection? & Yes/No \\
\hline $\begin{array}{l}\text { 18. During } 14 \text { days before the infection, did you have contact with anyone who had come back } \\
\text { from abroad? }\end{array}$ & Yes/No \\
\hline 19. During 14 days before the infection, did you have contact with anyone in quarantine? & Yes/No \\
\hline $\begin{array}{l}\text { 20. Are there any cases of COVID-19 among people you are close to (same household } \\
\text { or direct contact for } \geq 15 \text { min every day)? }\end{array}$ & Yes/No \\
\hline 21. Would you get vaccinated if there were a vaccine? & Yes/No \\
\hline 22. Do you smoke? & Yes, often/Rarely/No \\
\hline $\begin{array}{l}\text { 23. How many people are there in your household? Give the total number, and the numbers } \\
\text { of children and people aged } \geq 65 \text { years. }\end{array}$ & $\begin{array}{l}\text { Total } \_ \text {Children } \\
\text { People aged } \geq 65 \text { years }\end{array}$ \\
\hline 24. In which country do you work? & Poland/Other country \\
\hline 25. How many people are employed in your company? & $<10,10-100,>100$ \\
\hline \multicolumn{2}{|l|}{ 26. How many people at work do you have contact with during a usual day? } \\
\hline $\begin{array}{l}\text { 27. Before you got infected, did you use personal protective equipment at work } \\
\text { (masks, visors, gloves, hand rub)? }\end{array}$ & $\begin{array}{l}\text { Yes, always/Nearly always/ } \\
\text { Sometimes/Nearly never/Never }\end{array}$ \\
\hline 28. What was the date when the symptoms first appeared? & -1 \\
\hline 29. What was the date of the test result confirming COVID-19? & 1 \\
\hline \multicolumn{2}{|l|}{ 30. Have you observed the following symptoms: } \\
\hline 30.1 loss of appetite & Yes/No \\
\hline 30.2 loss of smell & Yes/No \\
\hline
\end{tabular}


Table 1. Structured interview questions for patients infected with COVID-19 who remained in home isolation on April 17-18, 2020 (Warsaw, Poland) - cont.

\begin{tabular}{ll}
\hline \multicolumn{1}{c}{ Question } & Answer \\
\hline 30.3 loss of taste & Yes/No \\
30.4 diarrhea & Yes/No \\
31. Do you have any of the following conditions: & \\
31.1 hypertension & Yes/No \\
31.2 diabetes & Yes/No \\
31.3 heart disease (coronary heart disease, myocardial infarction, heart failure) & Yes/No \\
31.4 chronic kidney disease & Yes/No \\
31.5 chronic lung disease & Yes/No \\
\hline
\end{tabular}

2122 agreed to take part (Figure 1). The response rate was $43.5 \%$ (41.8\% among males and $43.8 \%$ among females). The median age of the patients included in the study was 50 years (range: 18-99 years); 59\% were female. The median time from the symptom onset to the confirmation of the disease by RT-PCR was 2 days. About 1 in 10 people ( $9 \%$ of all patients) in the study admitted that they had contact with other people since confirmation of a positive result on the laboratory test for COVID-19.

\section{Source of infection}

Most patients (92\%) had not been abroad before the infection, and $87 \%$ did not have contact with people who
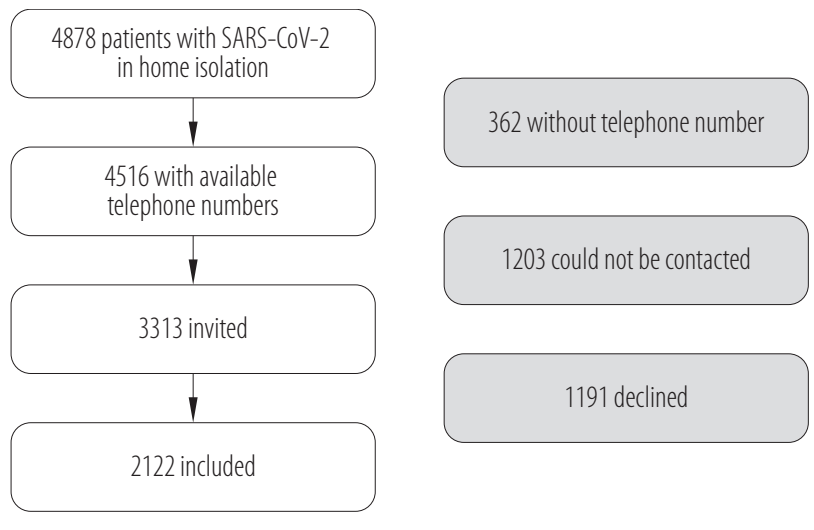

Figure 1. Flow diagram showing the inclusion process for the study cohort of patients infected with SARS-CoV-2 who remained in home isolation on April 17-18, 2020, Poland had returned from abroad. More than half $(55 \%)$ knew how they became infected (self-reported awareness of the settings of SARS-CoV-2 transmission). Among the patients who declared awareness of the source of infection, $75 \%$ became infected at work. Sixty-five percent of all occupationally active patients worked in companies with $>100$ employees (<10 employees - 10\%; 10-100 employees $-25 \%$ ) (Figure 2).

\section{Occupational status}

Of all patients, $70 \%$ were occupationally active (in line with the Classification of Occupations and Specialties by

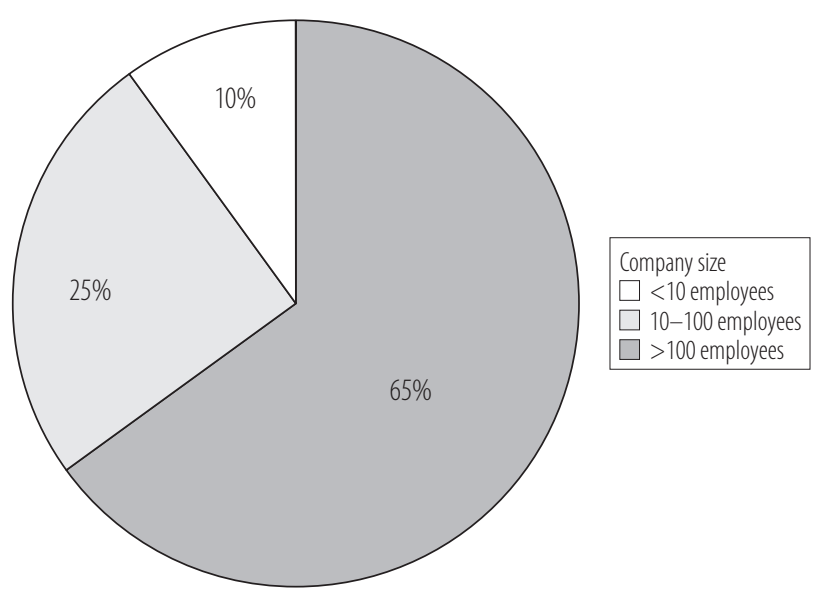

Figure 2. Company size among the occupationally active people infected with SARS-CoV-2 who remained in home isolation on April 17-18, 2020, Poland 
Statistics Poland); 97\% worked in Poland. Almost half of the occupationally active patients (48\%) worked in healthcare, $3 \%$ worked in public administration or defense, $3 \%$ worked in transportation, and $2 \%$ worked in education (Figure 3). The remaining occupational areas accounted for $\leq 1 \%$ of all cases each; $24 \%$ of the respondents had an unclassified occupational area.

In terms of their profession, $25 \%$ of the occupationally active patients were nurses, $9 \%$ were physicians, $3 \%$ were medical caretakers, $3 \%$ were cleaners in hospitals, $2 \%$ were policemen, and $2 \%$ were drivers (Figure 4). The remaining professions accounted for $\leq 1 \%$ of all cases each; $40 \%$ of occupations were unclassified. Personal protective equipment (PPE) for COVID-19 (in line with the WHO guidance [15]) at work was always used by $60 \%$ of the occupationally active patients, nearly always used by $16 \%$, sometimes used by $9 \%$, and nearly never or never used by $16 \%$.

\section{DISCUSSION}

This study found that about $90 \%$ of the patients with SARS-CoV-2 who remained in home isolation had not gone abroad or had no contact with people from abroad. Only half of the patients knew how they became infected (self-reported knowledge of the source of infection). Of them, three-quarters were infected at work, primarily in healthcare facilities. Workplace-related infections occurred even though most patients declared regular use of PPE at work.

These data confirm that the transmission of SARS-CoV-2 in Poland is local, with a vast majority of infections occurring within the country's borders. As expected, the patients involved in the study, who all had asymptomatic or mild forms of the disease, were, on average, younger and healthier than patients with COVID-19 who require treatment in hospital. The median age in the sample was 50 years, whereas severe COVID-19 is considerably more common in people aged $\geq 65$ years [16]. Similarly,

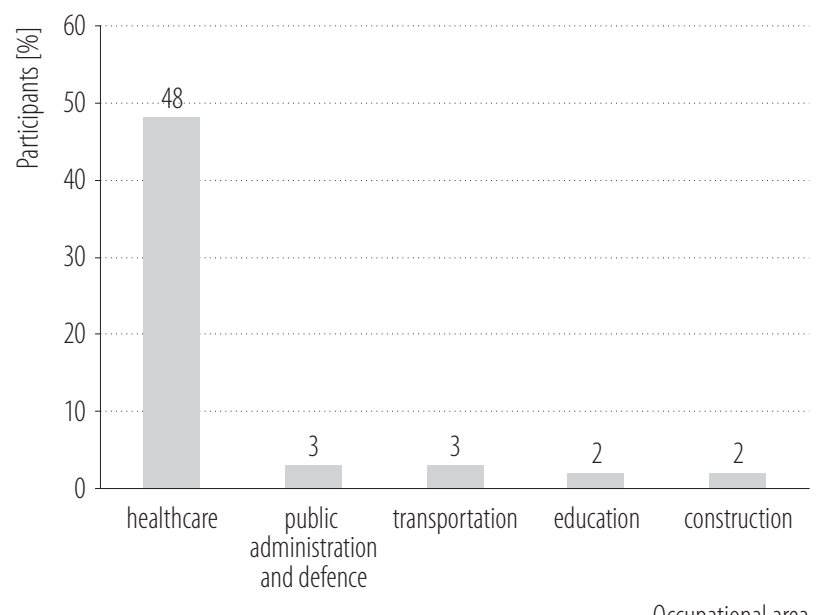

The remaining areas accounted for $\leq 1 \%$ of all cases and are not shown.

Figure 3. Most common occupational areas among the occupationally active people infected with SARS-CoV-2 who remained in home isolation on April 17-18, 2020, Poland

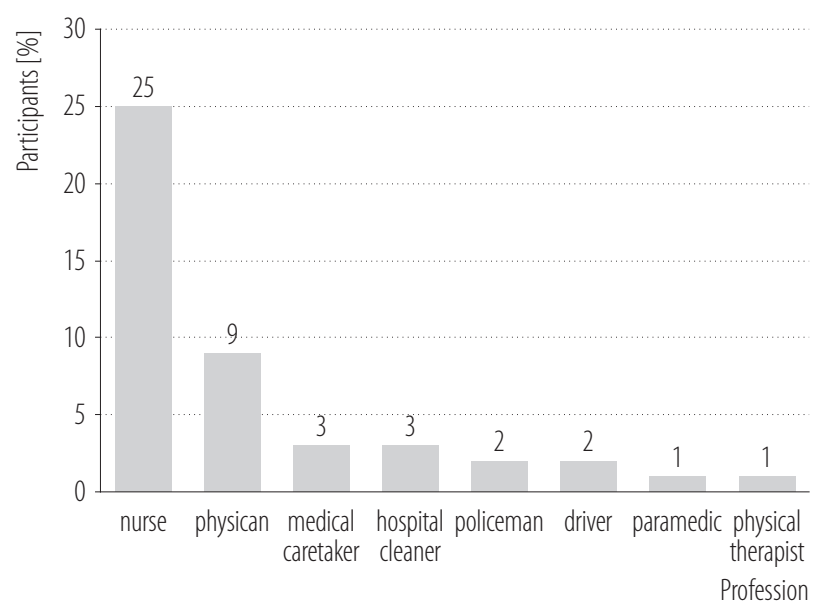

The remaining professions accounted for $\leq 1 \%$ of all cases and are not shown.

Figure 4. Most common professions among the occupationally active people infected with SARS-CoV-2 who remained in home isolation on April 17-18, 2020, Poland

the prevalence of chronic diseases that increase the risk of severe COVID-19, such as cardiovascular or respiratory diseases, was low in this cohort (data submitted for publication) [17].

As of April 17, 2020, there were 8379 laboratory-confirmed COVID-19 cases reported in Poland (including 332 deaths 
and 866 recovered) [18]. An epidemiological analysis of the first 1157 confirmed COVID-19 cases showed that women represented $50.5 \%$ of these [19]. More than onethird of the confirmed cases $(33.9 \%)$ were people aged 30-49 years [19]. According to the Chief Sanitary Inspectorate, as of April 11, 2020, women represented 55.5\% of the COVID-19 cases in Poland (median age: 50 years) [20]. A demographic characteristic of the examined group in this study is comparable to those reported by the Chief Sanitary Inspectorate in the total group of COVID-19 cases in Poland.

An important observation of this study is that threequarters of infections with a known source occurred at the workplace, and nearly half of all patients were healthcare professionals. This finding is understandable, as healthcare professionals are exposed to the virus more often. Indeed, these data are in line with previous reports that healthcare-related SARS-CoV-2 infections represent a substantial proportion of all SARS-CoV-2 infections [21-23]. Importantly, although most patients in this study declared that they had used PPE, they still acquired the infection. Although the authors did not gather data on the types of PPE used, it seems to be insufficient in the cohort. Unfortunately, shortages of appropriate PPE for healthcare workers are problematic worldwide because of the unprecedented scale of the SARS-CoV-2 epidemic [24]. Providing PPE for healthcare workers in adequate quantities seems essential to maintain the workforce throughout the epidemic; however, other ways of improving the safety of healthcare professionals, such as routine testing at the workplace, should also be considered [25].

According to the ECDC rapid risk assessment report (as of April 23, 2020), nosocomial transmission is the prevalent setting of SARS-CoV-2 infections in Europe. In Italy, $>17000$ healthcare professionals had been infected (10\% of all registered infections in Italy) [26]. In Spain, $20 \%$ of COVID-19 cases were among healthcare work- ers [26]. In Poland, similarly as in other European countries, healthcare-related SARS-CoV-2 infections represent a substantial proportion of all infections.

The frequency of SARS-CoV-2 infections among other professions was much lower than that observed in the healthcare industry. Indeed, only $3 \%$ of these cases worked in public administration or defense, and 3\% worked in transportation. These are the key professions whose members continued to work despite the lockdown measures introduced in Poland.

Most patients with COVID-19 worked in companies that employed $>100$ people. It is conceivable that in larger companies the virus can spread to more people before it is detected. Moreover, infections among healthcare professionals, who usually work in facilities employing $>100$ people, may have contributed to this finding. The observation that the risk of acquiring a SARS-CoV-2 infection at work seems to be lower in small companies may be important from an economic standpoint. It is reasonable to suggest that the reopening of the economy should begin with small companies. To further reduce the infection risk at work, WHO has put forward a document suggesting several preventive actions, including disinfection of surfaces, hand hygiene, and respiratory hygiene, among others [27].

About 1 in 10 people in this study admitted that they had breached isolation rules by contacting other people. Such non-compliance reduces the effectiveness of home isolation, which could be why home isolation is less effective than institutional isolation [28,29]. Self-isolation is difficult, and observing all self-isolation rules may be challenging for many people. Therefore, it is essential to look for measures that can improve compliance with home isolation. A study from Israel found that compliance with a self-isolation regimen was $94 \%$ when financial compensation was given, but it decreased to $57 \%$ when the compensation was removed [30]. The psychological impact of self-isolation may be lowered by providing basic supplies 
and clear information on the aims and protocols of isolation [31]. One group suggested that compliance with home isolation might be increased through public strategies to foster moral obligation and trust in public authorities [32]. In the present study, nearly half of the patients with COVID-19 in home isolation transmitted the disease to another person. In an earlier study, secondary transmission in household contacts was only $16 \%$ [33]. Although it would be preferable to isolate patients infected with SARS-CoV-2 outside of their home, to reduce the transmission risk within the same household, this strategy seems unfeasible because of the large scale of the epidemic.

Certain limitations of this study need to be mentioned. First, the data gathered in this study came from subjective declarations. This approach seems to be less reliable than using official reports. For example, the contacts between patients and their local sanitary-epidemiological stations could be verified through official reports. However, this seems unfeasible in such a large study sample. Similarly, when asked directly, people may tend to overestimate their compliance with isolation measures or not to disclose any breaches of the isolation rules. Second, the study included patients with confirmed infections only; therefore, the results may not be representative of the wider Polish population. For example, there may be a bias towards testing some professional groups more often than others. The strengths of this study include a large cohort, which was recruited by contacting all patients in home isolation during the study period.

\section{CONCLUSIONS}

Most of the patients with COVID-19 in home isolation in Poland are occupationally active, wherein the majority of people who were aware of the source of SARS-CoV-2 infection worked in healthcare. As most of the infected patients worked in companies with $>100$ workers, which is not a Polish employment pattern, the authors expect that smaller companies may have a lower risk of SARS$\mathrm{CoV}-2$ infections. This finding should be considered when planning strategies for liberating economic restrictions as it indicates industries that require particularly stringent sanitary guidelines.

\section{ACKNOWLEDGMENTS}

The authors would like to thank Rafał Szot (Proper Medical Writing, Warsaw, Poland) for his assistance with the preparation of the manuscript, and Julia Bates (Proper Medical Writing, Warsaw, Poland) for her professional editing and language assistance.

\section{REFERENCES}

1. World Health Organisation [Internet]. Coronavirus disease (COVID-19) Situation Report-107. Geneva: The Organization; 2020 [cited 2020 May 11]. Available from: https:// www.who.int/docs/default-source/coronaviruse/situationreports/20200506covid-19-sitrep-107.pdf?sfvrsn = 159c3dc_2.

2. Bendavid E, Mulaney B, Sood N, Shah S, Ling E, BromleyDulfano R, et al. COVID-19 Antibody Seroprevalence in Santa Clara County, California. MedRxiv. 2020;20062463, https://doi.org/10.1101/2020.04.14.20062463.

3. Harapan H, Itoh N, Yufika A, Winardi W, Keam S, Te H, et al. Coronavirus disease 2019 (COVID-19): A literature review. J Infect Public Health. 2020;13(5):667-73, https://doi. org/10.1016/j.jiph.2020.03.019.

4. Liu J, Liao X, Qian S, Yuan J, Wang F, Liu Y, et al. Community Transmission of Severe Acute Respiratory Syndrome Coronavirus 2, Shenzhen, China, 2020. Emerg Infect Dis. 2020;26(6):1320-3, https://doi.org/10.3201/eid2606.200239.

5. Akin L, Gözel MG. Understanding dynamics of pandemics. Turkish J Med Sci. 2020;50(3):515-9, https://doi.org/10.3906/ sag-2004-133.

6. Hellewell J, Abbott S, Gimma A, Bosse NI, Jarvis CI, Russell TW, et al. Feasibility of controlling COVID-19 outbreaks by isolation of cases and contacts. Lancet Glob Health. 2020;8(4): e488-96, https://doi.org/10.1016/S2214-109X(20)30074-7. 
7. Marcel S, Christian AL, Richard N, Silvia S, Emma H, Jacques F, et al. COVID-19 epidemic in Switzerland: On the importance of testing, contact tracing and isolation. Swiss Med Wkly. 2020;150:w20225, https://doi.org/10.4414/smw. 2020.20225 .

8. Burke RM, Midgley CM, Dratch A, Fenstersheib M, Haupt T, Holshue M, et al. Active Monitoring of Persons Exposed to Patients with Confirmed COVID-19 - United States, January-February 2020. MMWR Morb Mortal Wkly Rep. 2020;69(9):245-6, https://doi.org/10.15585/mmwr.mm6909e1.

9. Day M. Covid-19: four fifths of cases are asymptomatic, China figures indicate. BMJ. 2020;369:m1375, https://doi. org/10.1136/bmj.m1375.

10. Wu Z, McGoogan JM. Characteristics of and Important Lessons from the Coronavirus Disease 2019 (COVID-19) Outbreak in China: Summary of a Report of 72314 Cases from the Chinese Center for Disease Control and Prevention. JAMA. 2020;323(13):1239-42, https://doi.org/10.1001/jama.2020.2648.

11. He X, Lau EHY, Wu P, Deng X, Wang J, Hao X, et al. Temporal dynamics in viral shedding and transmissibility of COVID-19. Nat Med. 2020;26:672-5, https://doi.org/10.1038/ s41591-020-0869-5.

12. Chief Sanitary Inspector [Internet]. Recommendations for people infected with SARS-CoV-2 who do not need hospitalization 2020. Warsaw: The Chief Sanitary Inspectorate; 2020 [cited 2020 May 7]. Available from: https:/nipip. pl/wp-content/uploads/2020/03/03-Zalecenia-PTEiLChZ_ izolowani-poza-szpitalem_22.03.2020.pdf).

13. European Centre for Disease Prevention and Control (ECDC) [Internet]. Case definition and European surveillance for COVID-19, as of 2 March 2020. Solna: The Centre; 2020 [cited 2020 May 12]. Available from: https://www.ecdc. europa.eu/en/case-definition-and-european-surveillancehuman-infection-novel-coronavirus-2019-ncov.

14. Central Statistical Office [Internet]. [The Classification of Occupations and Specialties]. Warsaw: The Office; 2020 [cited 2020 May 11]. Available from: https://stat.gov.pl/Klasyfikacje/doc/kzs/slownik.html. Polish.
15. World Health Organization [Internet]. Rational use of personal protective equipment for coronavirus disease (COVID-19): interim guidance, 27 February 2020. Geneva: The Organization; 2020 [cited 2020 May 12]. Available from: https://apps.who.int/iris/handle/10665/331215.

16. Zhou F, Yu T, Du R, Fan G, Liu Y, Liu Z, et al. Clinical course and risk factors for mortality of adult inpatients with COVID-19 in Wuhan, China: a retrospective cohort study. Lancet. 2020;395:1054-62, https://doi.org/10.1016/S0140-6736 (20)30566-3.

17. Zheng Z, Peng F, Xu B, Zhao J, Liu H, Peng J, et al. Risk factors of critical and mortal COVID-19 cases: A systematic literature review and meta-analysis. J Infect. 2020;S01634453(20):30234-6, https://doi.org/10.1016/j.jinf.2020.04.021.

18. World Health Organization [Internet]. Coronavirus disease 2019 (COVID-19) Situation Report - 89. Geneva: The Organization; 2020 [cited 2020 May 11]. Available from: https:// www.who.int/docs/default-source/coronaviruse/situationreports/20200418-sitrep-89-covid-19.pdf?sfvrsn=3643dd38_2.

19. Gujski M, Raciborski F, Jankowski M, Nowicka PM, Rakocy K, Pinkas J. Epidemiological Analysis of the First 1389 Cases of COVID-19 in Poland: A Preliminary Report. Med Sci Monit. 2020;26:e924702, https://doi.org/10.12659/MSM. 924702.

20. Chief Sanitary Inspectorate [Internet]. [COVID-19 cases in Poland]. Warsaw: The Inspectorate; 2020 [cited 2020 May 11]. Available from: https://gis.gov.pl/aktualnosci/strukturazachorowan-na-covid-19-w-podziale-ze-wzgledu-na-plec-wpolsce/. Polish.

21. Ran L, Chen X, Wang Y, Wu W, Zhang L, Tan X. Risk Factors of Healthcare Workers with Corona Virus Disease 2019: A Retrospective Cohort Study in a Designated Hospital of Wuhan in China. Clin Infect Dis. 2020;ciaa287, https://doi. org/10.1093/cid/ciaa287.

22. Wang D, Hu B, Hu C, Zhu F, Liu X, Zhang J, et al. Clinical Characteristics of 138 Hospitalized Patients With 2019 Novel Coronavirus-Infected Pneumonia in Wuhan, China. JAMA. 2020;323(11):1061-9, https://doi.org/10.1001/jama.2020.1585. 
23. Parra A, Rising D. Spain's coronavirus death toll surpasses China as world struggles with containment [Internet]. Global News. 2020 March 25 [cited 2020 May 12]. Available from: https://globalnews.ca/news/6729174/coronavirusspain-death-toll-china/.

24. Ranney ML, Griffeth V, Jha AK. Critical Supply Shortages The Need for Ventilators and Personal Protective Equipment during the Covid-19 Pandemic. N Engl J Med. 2020; 382(18):e41, https://doi.org/10.1056/NEJMp2006141.

25. Hunter E, Price DA, Murphy E, van der Loeff IS, Baker KF, Lendrem D, et al. First experience of COVID-19 screening of health-care workers in England. Lancet. 2020;395 (10234):e77-8, https://doi.org/10.1016/S0140-6736(20)309 70-3.

26. European Centre for Disease Prevention and Control [Internet]. Rapid risk assessment. Coronavirus disease 2019 (COVID-19) in the EU/EEA and the UK - ninth update, 23 April 2020. Solna: The Centre; 2020 [cited 2020 May 9]. Available from: https://www.ecdc.europa.eu/sites/default/ files/documents/covid-19-rapid-risk-assessment-coronavirus-disease-2019-ninth-update-23-april-2020.pdf.

27. World Health Organisation [Internet]. Getting your workplace ready for COVID-19. Geneva: The Organization; 2020 [cited 2020 May 11]. Available from: https://www.who.int/ docs/default-source/coronaviruse/getting-workplace-readyfor-covid-19.pdf?ua $=1$.
28. Dickens BL, Koo JR, Wilder-Smith A, Cook AR.Institutional, not home-based, isolation could contain the COVID-19 outbreak. Lancet. 2020;6736:1-2, https://doi.org/10.1016/S01406736(20)31016-3.

29. Sjödin H, Wilder-Smith A, Osman S, Farooq Z, Rocklöv J. Only strict quarantine measures can curb the coronavirus disease (COVID-19) outbreak in Italy, 2020. Eurosurveillance. 2020;25(13), https://doi.org/10.2807/1560-7917.ES.2020.25. 13.2000280 .

30. Bodas M, Peleg K. Self-Isolation Compliance By The COVID-19 Era Influenced By Compensation: Findings From A Recent Survey By Israel. Health Aff (Millwood). 2020;39(6): 936-41, https://doi.org/10.1377/hlthaff.2020.00382.

31. Brooks SK, Webster RK, Smith LE, Woodland L, Wessely S, Greenberg N, et al. The psychological impact of quarantine and how to reduce it: rapid review of the evidence. Lancet. 2020;395(10227):912-20, https://doi.org/10.1016/S0140-6736 (20)30460-8.

32. Nivette A, Ribeaud D, Murray AL, Steinhof A, Bechtiger L, Hepp U, et al. Non-compliance with COVID-19-related public health measures among young adults: Insights from a longitudinal cohort study. SocArXiv. Forthcoming 2020, https://doi.org/10.31235/osf.io/8edbj.

33. Li W, Zhang B, Lu J, Liu S, Chang Z, Cao P, et al. The characteristics of household transmission of COVID-19. Clin Infect Dis. 2020; ciaa450, https://doi.org/10.1093/cid/ciaa450.

This work is available in Open Access model and licensed under a Creative Commons Attribution-NonCommercial 3.0 Poland License - http://creativecommons.org/ licenses/by-nc/3.0/pl/deed.en. 